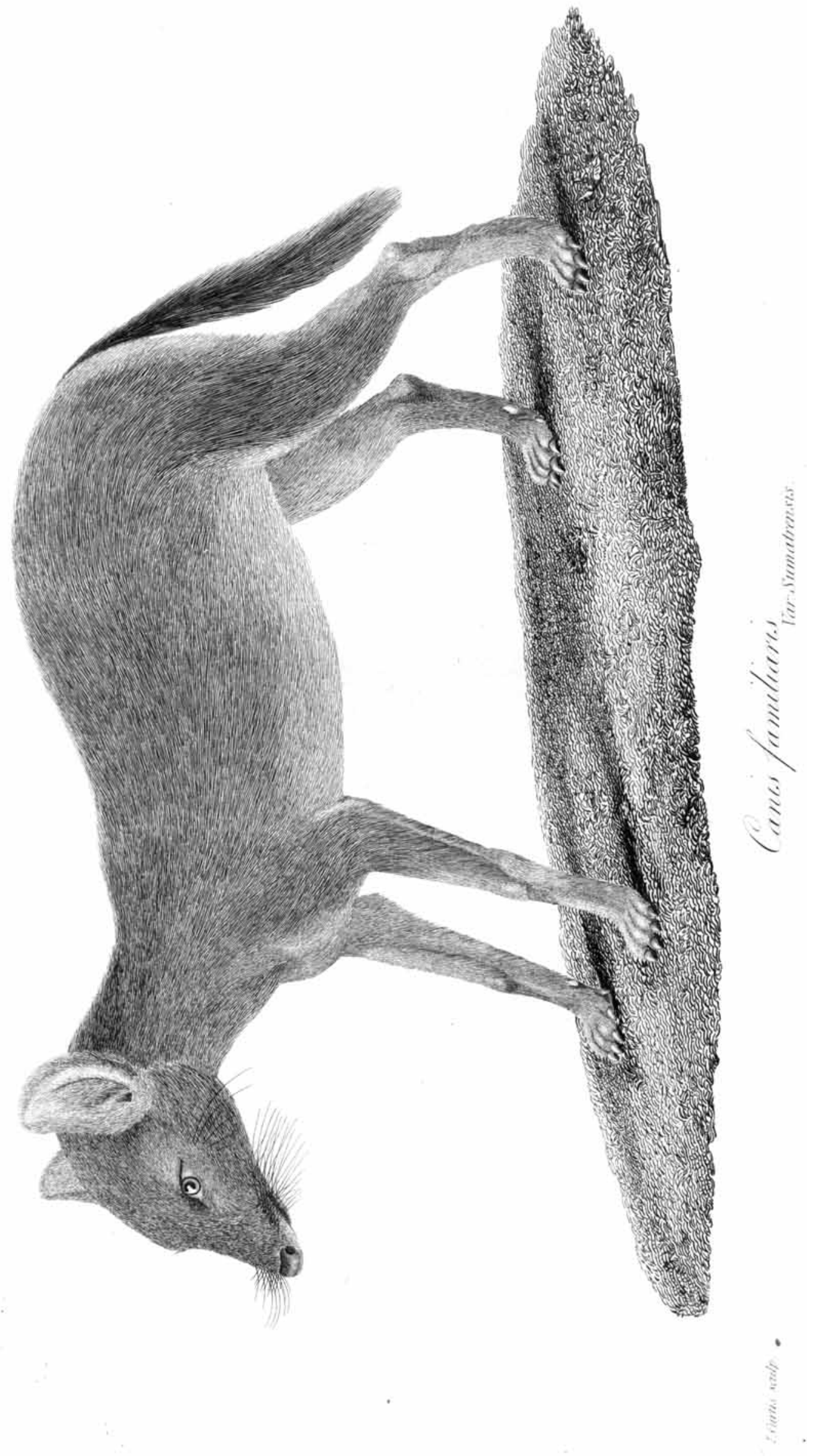


XVI. Descriptions of the Wild Dog of Sumatra, a new Species of Viverra, and a new Species of Pheasant. By Major-General Thomas Hardwicke, F.R.S. and L.S.

Read May 2, 1820.

CANIS familiaris. Var. Sumatrensis.

Wild Dog of Sumatra.

TAB. XXIII.

Countenance of a Fox; nose pointed; apex black; whiskers long and black; eyes oblique; ears erect, more rounded than in the common Fox or Jackall, very hairy; muzzle foxy brown much mixed with black; tail pendulous, bushy, most so about the middle, smaller at the origin; hair black, reaching to the leg-joint.

The animal stands high on its legs, which are long in proportion to its size. Feet firmly planted, but not resting on the heel ; toes four in front, large and strongly united; a fifth very small, on the inner side of the foot and remote from the rest; claws long, compressed, strong, not retractile; above the small toe is a round tubercle or callosity on each leg.

The general colour of the animal a foxy-ferruginous red, varying to lighter shades on the belly and inside the thighs.

The action of the animal in confinement is, like most other wild animals, restless in the extreme while any one stands near; and if teased, it emits a most fœetid urine. Its voice is more of a cry than a bark.

The length of the subject about 24 inches; height 14 inches.

2 н 2

The 
236 Major-Gen. Ha d w ick E On the Wild Dog of Sumatra,

'The resemblance between this animal and the Wild Dog of the Ramghur hills, called Quäo, is strikingly close ; the colour of both is the same, the black bushy tail the same, as also the form of the nose; but the ears of the Sumatra Dog are more rounded.

It has also a great affinity to the Dog of New \%ealand. One of these animals was exhibited in the Museum of Mr. Brooks, Blenheim-street, Great Marlborough-street, in April 1815.

\section{VIVERRA? Linsayg.}

\section{Taв. XXIV.}

Head small, ovate, much pointed, finely tapering, the upper jaw much longer than the under; whiskers numerous, setaceous; longer than the head, pointing backwards; eyes equi-distant between the nose and ears, small, circular; ears rounded, of a moderate size; neck almost twice the length of the head; body twice the length of the neck; tail nearly as long as the body, cylindrical ; legs of nearly equal length, and, in proportion to the size of the animal, rather long ; feet in proportion, planted like those of the feline genus; toes five on each foot, before and behind; claws very small, retractile, and so obscured in the fur as to be hardly visible.

The general colour of the animal is a yellowish-white, covered with longitudinal broad lines, and long confluent spots of black; the spots on the legs and lowest line of the abdomen more distinct.

The tail annulated with six bands of black, alternating with as many of the ground colour of the animal, yellowish-white. The belly, under-part of neck and inner side of the legs yellowish-white; nose black, and a black streak extending from the posterior corner of the eye to the side of the neck.

Length 


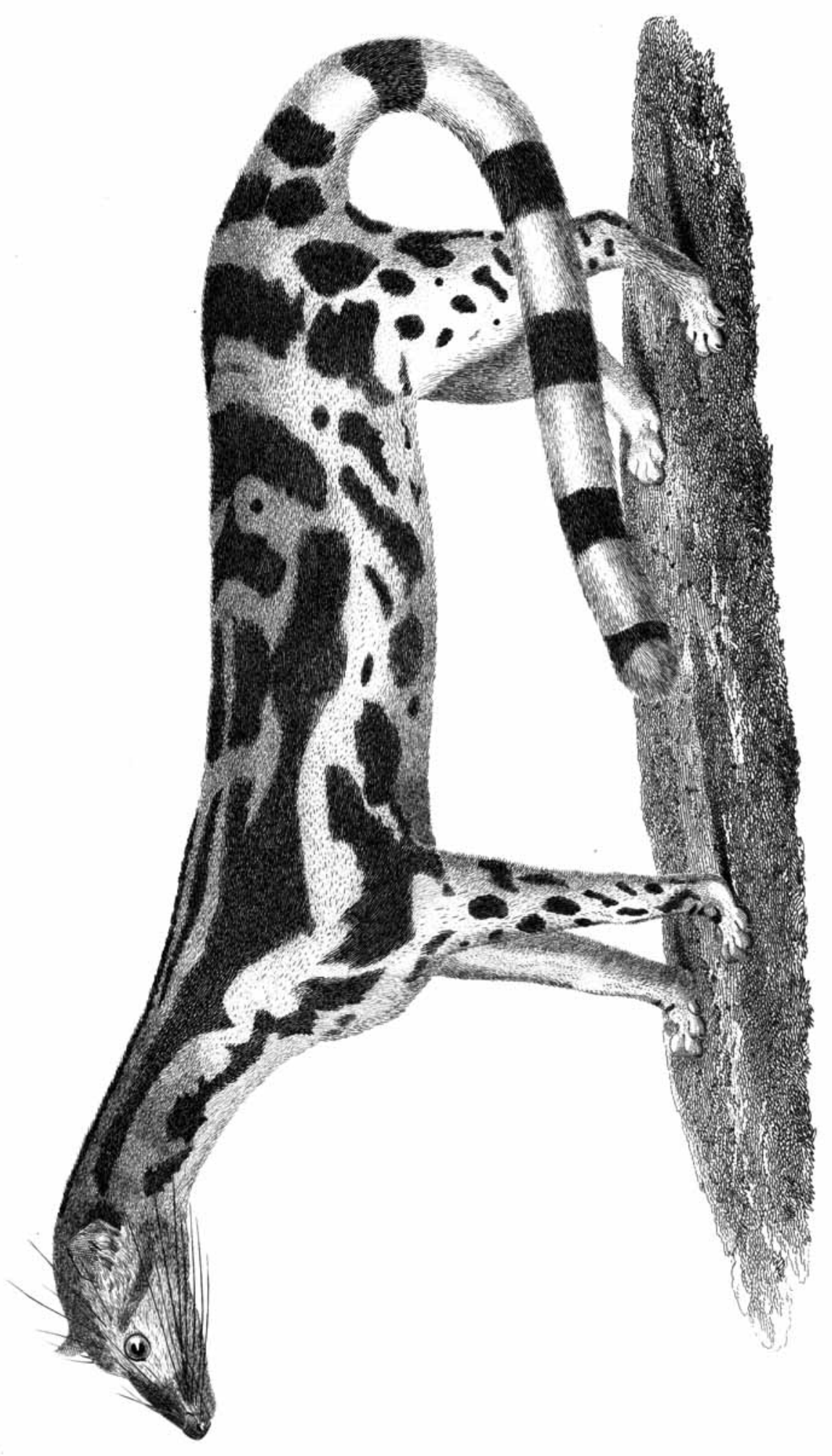

है 
a new Species of Viverra, and a new Species of Pheasant. 237

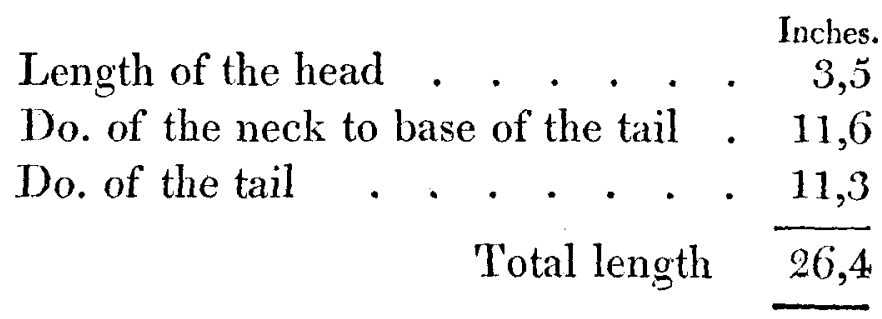

The height of the animal to the nose when standing $\quad \begin{gathered}\text { Inches } \\ 8,7 \frac{3}{4}\end{gathered}$

At the rump . . . . . 6,3

$\Lambda$ knowledge of this animal was communicated to the Asiatic Society by Major Farquhar, from Malacca, from whence he sent a dead specimen. In most respects the specimen was in good condition, but the teeth were wanting.

It is a native of the island of Java, and is said to be a carnivorous animal.

\section{PHASIANUS CRUENTUS.}

Size of a small fowl; length seventeen inches; bill short, $\frac{8}{10}$ of an inch, convex, very strong, black, the base red, including. the nostrils; temples naked; skin red, but feathered between the bill and the eye; from the base of the upper mandible rises a small crest of short various coloured feathers, inclining backward.

The colour of the plumage above is dark ash, with white shafts, the coverts of the wings variously tinged with green, with broad strokes of white through the length of each feather; primaries and secondaries brownish-black, with white shafts; the feathers of the chin deep crimson, neck much mixed with white; on the breast, belly and sides the feathers are lanceshaped, of various length, the tips green with crimson margins, collectively resembling dashes of blood scattered on the breast and belly; vent rufous. The tail consists of twelve 
$238 M a j .-G e n$. Har dw те ке On the Wild Dog of Sumatra, \&c.

sub-equal feathers, about six inches in length ; shafts white, rounded, the ends whitish; the coverts both above and beneath a rich crimson red.

Legs deep red, armed with three unequal spurs, but varying in number in different subjects; toes long; claws strong, long and black.

The hen is similar to the cock in plumage and all other marks, but smaller and without spurs.

This fine species of Pheasant is a native of the Nepaul hills; and it is to the liberal contributions of the Honourable Edward Gardner, Resident at the Court of Nepaul, that I am indebted for the opportunity of presenting to the Linnean Society this description, from well preserved dead subjects in my possession. 